\title{
The Nature and Role of User Beliefs Regarding a Website's Design Quality
}

\author{
Camille Grange, HEC Montreal, Montreal, Canada \\ Henri Barki, HEC Montreal, Montreal, Canada
}

\begin{abstract}
Researchers and practitioners have long been interested in identifying the criteria that users consider important in assessing whether a system is worth using. However, past research in this domain has not taken into account the characteristics of a system's design and their quality in a systematic and comprehensive manner, which is likely to have limited the development of actionable design guidelines. The article addresses this issue by suggesting a research model that links user beliefs-which have traditionally been used in IT acceptance and success research (i.e., information quality, system quality, usefulness, and ease of use) - to their beliefs regarding the quality of three categories of a system's design (i.e., visual quality, page layout quality, and navigation quality) and testing it in the context of organizational intranets. The analysis of data collected from 159 intranet website users in three organizations supported the model, suggesting that the three categories of design quality beliefs significantly influenced users' assessment of their system's information quality and system quality.
\end{abstract}

\section{KEYWORDS}

Design Quality Beliefs, Human-Computer Interaction, IT Acceptance, Navigation Quality, Page Layout Quality, User Experience, Visual Quality, Web Design

\section{INTRODUCTION}

The success (or failure) of organizational information technologies (ITs) is likely to be affected by the perceptions and thinking of employees who use these ITs in their daily work. For example, while users' frustration with a newly implemented IT in an organization can result in its discontinuance and wasted resources, satisfied users can positively influence success (DeLone \& McLean, 2003). Given the importance of user judgments regarding the quality of their interaction with an IT, and in order to explain and predict why individuals adopt and use ITs, a substantial amount of research has examined perception-based models that are grounded in social psychology. For example, one of the most well-known of these models, the Technology Acceptance Model (TAM), explains and predicts users' intentions to use an IT based on their beliefs about its ease of use and usefulness (Davis, Bagozzi \& Warshaw, 1989).

Since its introduction, a prolific stream of research has validated and extended TAM by identifying antecedents of its key constructs, i.e., usefulness and ease of use, and by providing valuable practical recommendations, such as how to design managerial interventions (e.g., policy, marketing, training) to increase the likelihood of user adoption of a new system - especially by those who would be more inclined to resist it (Venkatesh, Morris, Davis, \& Davis, 2003). However, past research in this domain has not systematically examined how a system's design characteristics can facilitate more effective user-system interactions. The presence of this knowledge gap has already been underscored as a 
concern (e.g., Lee, Kozar \& Larsen, 2003; Venkatesh \& Bala, 2008), as it hinders the development of specific guidelines and identifying different IT design initiatives which can help improve users' evaluations of their organizational ITs (Benbasat \& Barki, 2007). In an effort to address this gap, the present paper proposes and empirically examines the influence of design quality beliefs, i.e., users' subjective probability judgments about discriminable design characteristics of a website (Al-Natour \& Benbasat, 2009). It is important to note that the present study focuses on three categories of such beliefs, namely those regarding a system's visual, page layout, and navigation quality, which pertain to how content is delivered on a website (Tarafdar \& Zhang, 2005). Beliefs that focus on what content an IT offers (e.g., its functionalities, the information it provides) are out of the scope of the present study because such characteristics can greatly vary between specific websites ${ }^{1}$.

In essence, the objective of the present study is to examine the influence of design-specific constructs on the well-known indicators of overall user experience, such as satisfaction, usefulness, and ease of use, that past research has heavily focused on. The present study also seeks to contribute to practice by identifying guidelines for conducting finer diagnostics regarding the quality of users' interactions with websites and help designers improve such interactions and enhance the user experience.

The next sections of the paper synthesize four streams of research that have identified criteria via which users tend to evaluate IT, namely IT acceptance, usability, web quality, and IT success. Then, a research model that extends existing acceptance theory via three design quality constructs (page layout quality, navigation quality, and visual quality) is developed, followed by a description of the methodology employed for testing it empirically, its results and findings, as well as a discussion of the study's contributions and its limitations.

\section{USER EVALUATIONS OF INFORMATION TECHNOLOGIES}

Existing streams of research on the acceptance, usability, quality, and success of IT have complementary strengths and limitations regarding their ability to explain and predict how users assess their experience with an IT. As explained below, research on user acceptance has strong theoretical foundations, but provides a limited account of design factors; research on usability is more design-focused, but lacks theoretical grounding, as well as linkage to other constructs relevant to IT use; research on website quality provides measurement instruments, but does not distinguish between different types of user evaluation constructs; and while research on IT success considers only a moderate level of design specificity, it also offers a useful theoretical platform for linking research on acceptance to research that focuses on IT design.

The general goal of IT research on user acceptance has been to better understand why individuals use ITs. Anchored in the Theory of Reasoned Action (TRA) (Fishbein \& Ajzen, 1975), TAM posited that user acceptance is generally driven by their perceptions of the extent to which an IT is easy to use (i.e., perceived ease of use, PEOU) and useful (i.e., perceived usefulness, PU) (Davis, 1989). Since its introduction, researchers have extended TAM by identifying antecedents of PU and PEOU by essentially focusing on user characteristics, such as computer self-efficacy, and contextual factors, such as social influence and organizational support, but have paid little attention to design characteristics (Benbasat \& Barki, 2007; Evermann \& Tate, 2009). Although a few researchers did examine design aspects, their studies have largely been specific to either a particular domain or a function, rather than being general (e.g., Cenfetelli, Benbasat \& Al-Natour, 2008; Davis, 1993; Hong, Thong, Wong \& Tam, 2001). Thus, while TAM has important strengths for identifying salient user judgments about the context and use of an IT, including a solid theoretical foundation, high predictive power, generalizability, and ease of operationalizability (Lee et al., 2003; Venkatesh, Davis \& Morris, 2007), it does not focus on how an IT's design influences its users' beliefs, attitudes, and usage of that IT.

Interestingly, a different stream of research has focused on the notion of usability as an alternative lens for explaining IT use by identifying design criteria that can be relevant to predicting the use 
of different types of ITs, such as mobile sites (Venkatesh \& Venkataraman, 2006), e-commerce sites (Venkatesh \& Agarwal, 2006), and mobile apps (Hoehle \& Venkatesh, 2015). This stream has identified useful guidelines regarding how to modify relatively specific design quality constructs, such as those that pertain to a system's information structure and labeling, its language, user control mechanisms, or graphical displays. However, as some researchers have noted, this stream of research tends to lack strong theoretical foundations, leading to conceptual ambiguities and overlaps (Tractinsky, 2018; Venkatesh \& Venkataraman, 2006). This issue also highlights a lack of clarity that exists regarding the boundaries of, and linkages between IT acceptance and usability constructs (Agarwal \& Venkatesh, 2002; Venkatesh \& Venkataraman, 2006), and suggests investigating whether “... usability characteristics are possible determinants of overall technology perceptions such as those described in technology acceptance theories" (Venkatesh \& Agarwal, 2006, p. 379). One of the few studies that have investigated this question attempted to incorporate into TAM a small set of design criteria, including task relevance, terminology, and screen design, and examined their influence on user beliefs (Hong et al., 2001). In sum, the usability literature still lacks a systematic and theoretically grounded approach for identifying a comprehensive and generalizable set of design quality beliefs that can be linked to acceptance research.

A related stream of work has focused on developing instruments that capture users' evaluation of websites. For example, Yoo \& Donthu (2001) interviewed students in order to develop an instrument (i.e., SITEQUAL) that measures the perceived quality of an Internet shopping site. After refining and testing the instrument's validity, the researchers grouped SITEQUAL items into four dimensions: ease of use, aesthetic design, processing speed, and security. Similarly, Barnes and Vidgen (2001, 2002 , 2012) also used an inductive approach to develop an instrument labeled WebQual. In its latest version that is specific to e-commerce sites, WebQual assessed five factors: usability, design, information quality, trust, and empathy, and a reduced form of it (iQual) applied to the intranet context excluded trust and empathy (Barnes \& Vidgen, 2012). In addition, Loiacono et al. (2007) used various techniques (e.g., literature review, exploratory surveys, expert judges) in order to specify 12 categories of user beliefs which form the basis of their WebQual instrument: informational fit-to-task, tailored information, trust, response time, ease of understanding, intuitive operations, visual appeal, innovativeness, emotional appeal, consistent image, on-line completeness, and relative advantage. While the studies of this stream have typically followed a rigorous instrument development process via multiple iterations of data collection and measurement validity tests, but they provide only a limited account of the nature of the proposed quality factors and have not examined their relationships. Moreover, they also did not specify how these factors relate to user evaluation constructs in relevant literatures, such as user acceptance (discussed above) or IT success (discussed next).

Finally, research on IT success has identified Information Quality and System Quality as two key antecedents of IT usage, user satisfaction, as well as of individual and organizational benefits (DeLone \& McLean, 1992, 2003; Petter, DeLone \& McLean, 2008; Petter, DeLone \& McLean, 2013; Rai, Lang \& Welker, 2002; Seddon, 1997). Information Quality refers to users' perceptions regarding the quality of the information provided by an IT, and covers aspects such as accuracy, completeness, currency, and understandability. System Quality represents the perceived quality of an IT's information processing and delivery system, and has been operationalized via aspects of accessibility, reliability, response time, flexibility, and integration (Nelson, Todd \& Wixom, 2005). Further, Wixom \& Todd (2005) have proposed an integrative model that specified Information Quality and System Quality as predictors of two key acceptance constructs, i.e., PU and PEOU, by drawing on TRA (Fishbein \& Ajzen, 1975), a theory that investigates the nature of psychological constructs. In an effort to extend Wixom \& Todd's (2005) nomological chain, the present study also drew on TRA in order to link factors that capture the perceived quality of an IT's design to Information Quality and System Quality. 


\section{RESEARCH MODEL}

\section{Theoretical Foundation: The Nature and Target of User Beliefs}

The Wixom \& Todd (2005) model is based on TRA (Fishbein \& Ajzen, 1975) which examines how individuals' beliefs influence their attitudes and behaviors. According to TRA, a belief is an individual's cognitively-derived subjective probability judgment that an entity has a specific attribute, and an attitude is a general affective assessment of an entity that arises from one's beliefs about that entity (Ajzen, 2001; Ajzen \& Fishbein, 2000). TRA distinguishes between two types of beliefs: those that target an object, such as the characteristic of someone or something, and those that target a behavior or its outcome (Al-Natour \& Benbasat, 2009). In addition, object-based beliefs may target object characteristics that can be more or less specific. Figure 1 summarizes the psychological constructs that are part of Wixom \& Todd's (2005) framework and identifies the target of these constructs in the context of individuals' interactions with a website.

According to TRA, specific properties of artifacts (e.g., the time a webpage takes to load), people (e.g., a job candidate's punctuality), and activities (e.g., the number of steps needed to order a product from a website) represent more concrete and reliable characteristics that influence one's beliefs than more abstract properties (e.g., the quality of a system, a candidate's fit to a job, the ease of using a website). Hence, Fishbein \& Ajzen (1975) suggested the examination of beliefs along a descriptive-to-inferential continuum, and following this suggestion, the present study identified a continuum of belief types that vary according to their target's abstraction level. As they intend to be more descriptive, design quality beliefs can be viewed as antecedents of Information Quality and System Quality. Highly descriptive beliefs stem from an individual's direct observation of a specific attribute of an object, while inferential beliefs are less closely derived from a direct perception of reality, and hence they tend to rely more on reasoning processes. For example, a customer's beliefs about the quality of an online firm are likely to be more inferential than his/her beliefs about how effective that firm's website is for placing orders, or some other salient and specific feature, such as the time it takes the firm's website to load. In addition, the former (i.e., beliefs about quality in general) tend to be informed by the latter (i.e., beliefs about specific quality elements). That is, when they tap into nested elements, descriptive and inferential beliefs can be expected to be causally related. Based on this reasoning, the research model of Figure 2 suggests three constructs for capturing users' design quality beliefs (Navigation Quality, Page Layout Quality, Visual Quality) as causal antecedents of the more inferential constructs of Information Quality and System Quality. The next sections explain these design quality constructs and the study hypotheses.

Figure 1. Nature and target of psychological constructs that reflect user evaluations

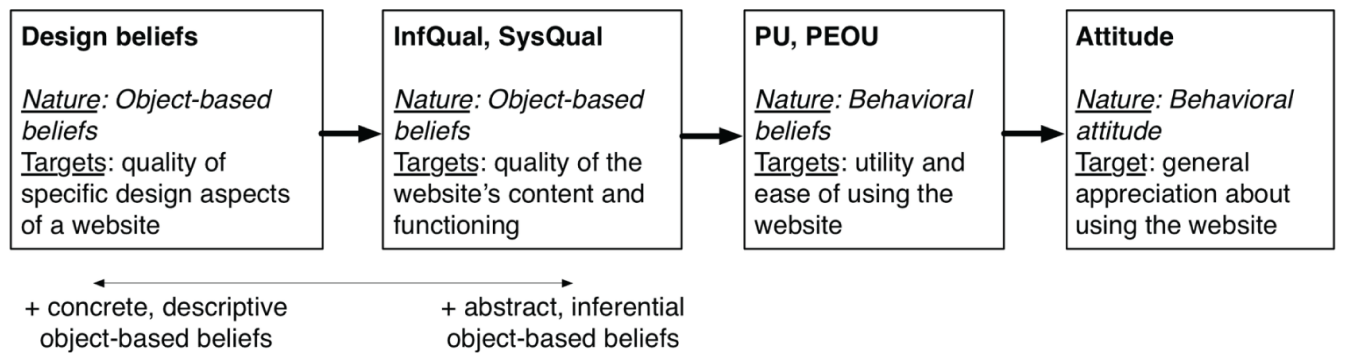

Keys: InfQual: Information Quality; SysQual: System Quality; PU: Perceived Usefulness; PEOU: Perceived Ease of Use 


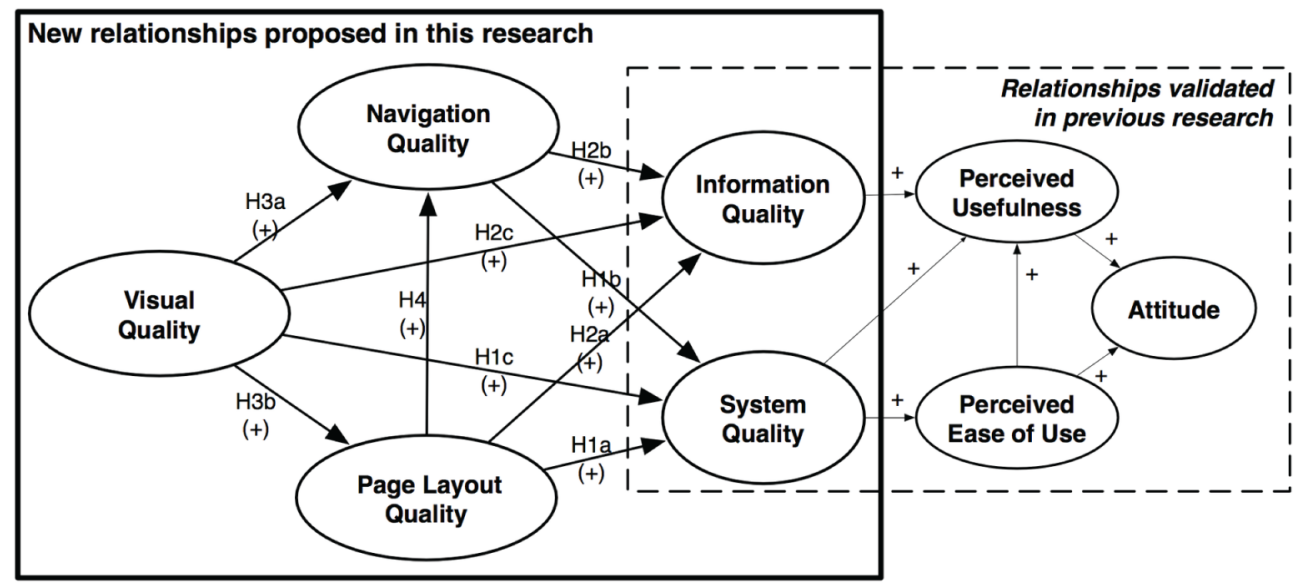

\section{Design Quality Beliefs}

The design quality beliefs that are suggested in the present study are based on an existing ontology which identifies three cornerstones to website design: information design, navigation quality, and visual quality (Cyr, 2008; 2014). Accordingly, information design pertains to "website elements that convey accurate or inaccurate information about products or services to a user" (Cyr, 2008, p. 52), navigation quality refers to "the navigational scheme used to help or hinder users as they access different sections of a website" (p. 54), and visual quality captures "elements that deal with balance, emotional appeal, aesthetics, and uniformity of the website overall graphical look" (p. 53). In order to adapt this framework to the present study's context of organizational intranets, two modifications were made. First, as characteristics that pertain to the quality of a website's informational output are already covered in the Information Quality construct, information design was excluded from the present study's research model in order to avoid conceptual overlaps between model constructs, as well as to be consistent with theory, i.e., the nomological network that underlies the research model (Figures 1 and 2). Second, the construct of Page Layout Quality was added to the model in order to capture elements of design that facilitate sense-making within web pages (versus making sense across pages or sections, which pertains to Navigation Quality). Both Page Layout Quality and Navigation Quality elements fit under the more general domain of information architecture. Thus, it is reasonable to think that Page Layout Quality and Navigation Quality can provide an adequate coverage of the design of a website's information architecture.

Based on the above considerations, the following three design quality constructs were included in the proposed research model: 1) Navigation quality, to reflect users' assessment of the effectiveness with which a website's navigation mechanisms help them move in its information space. Past research indicates that the content of this construct covers criteria that are instrumental in helping online users be more effective in their information search, including the relevance of information categories that are part of the architecture, the degree to which the scope of the architecture ensures an adequate coverage of the information, the speed with which its content is accessed, and the effectiveness of the navigation aids in helping users find their way towards what they are searching (Agarwal \& Venkatesh, 2002; Palmer, 2002; Shahizan \& Li, 2005); 2) Page layout quality, to reflect users' assessment of the effectiveness with which information is laid out on the pages of a website, including characteristics related to information presentation, organization, grouping, and finding, which are also important topics in the fields of information and library science (Toms, 2002), information systems (McKinney, Yoon \& Zahedi, 2002; Palmer, 2002; Vance, Elie-Dit-Cosaque \& Straub, 2008), and user 
experience (Garrett, 2002; Morville \& Rosenfeld, 2006); 3) Visual quality, to reflect users' assessment of the quality of a website's visual appearance. Past research strongly suggests that visual aspects influence perceived website quality (Lavie \& Tractinsky, 2004; Loiacono, Watson \& Goodhue, 2007; Sonderegger \& Sauer, 2010; Tractinsky, Katz \& Ikar, 2000; Vance et al., 2008), with information formatting, color contrasts, font sizes, and visual loads being viewed as key markers of a website's Visual Quality (Agarwal \& Venkatesh, 2002; Palmer, 2002; Shahizan \& Li, 2005).

\section{Influence of Design Quality Constructs on System Quality and Information Quality}

The specification of design quality constructs as descriptive beliefs whose targets, i.e., specific aspects of a website's design, are nested within the targets of constructs that reflect System Quality and Information Quality (Fishbein \& Ajzen, 1975) suggests a positive relationship between the three proposed design quality constructs and both System Quality and Information Quality. For example, if a user experiences smooth navigation within and across different sections of a website's information space, then she/he would be likely to positively assess Page Layout Quality and Navigation Quality, respectively; in turn, her/his evaluation of relatively specific design aspects is also likely to have a carryover influence on her/his more general evaluation of that site's functioning. Similarly, because Visual Quality taps into visual characteristics that enable users to access a website's information and functionalities, a positive assessment of a site's Visual Quality is also likely to lead to positive evaluations of its functioning. Overall, these considerations, which are consistent with TRA, suggest that the three proposed design quality beliefs are likely to positively influence System Quality (H1). In addition, it would also be reasonable to hypothesize a positive relationship between design quality beliefs and Information Quality because, when users evaluate a website's Information Quality, they not only develop their judgment based on content quality criteria, but they also tend to draw on their perceptions of how effective the website is in helping generate this content (Xu, Benbasat \& Cenfetelli, 2013). In contrast, an ineffective design can prevent users from accessing content they need, thus leading to low evaluations of the website's Information Quality. Hence:

H1: Page Layout Quality (H1a), Navigation Quality (H1b), and Visual Quality (H1c) will positively influence System Quality.

H2: Page Layout Quality (H2a), Navigation Quality (H2b), and Visual Quality (H2c) will positively influence Information Quality.

\section{Relationships Between Page Layout Quality, Navigation Quality, and Visual Quality}

Based on TRA's inference principle and past research, the proposed model suggests several relationships between the three design quality constructs. According to TRA's inference principle that underlies the formation of user beliefs, the three design quality constructs are likely to influence each other. For example, Visual Quality reflects user beliefs that are formed based on her/his evaluation of a website's visual features which help her/him access its information and functionalities, within and across its pages. As such, users' assessments of a website's ability to support navigation throughout the information space (navigation quality), as well as its support for wayfinding and sense making within its pages (page layout quality), are likely to be partly informed by their evaluations of the website's capacity to facilitate visual access to its information architecture and content. Thus, when interacting with a website, a user who experiences visual difficulties (e.g., insufficient color), would be likely to negatively assess the website's visual quality. In turn, such an assessment is also likely to result in negative evaluations of the website's page layout and navigation quality aspects because accessibility issues would prevent the user from effectively actualizing the website's informational and functional capabilities of the inference principle, which is suggested as an explanatory mechanism here, is also supported by past research in both system design and system use. Accordingly, not only a system must help users engage with the content and functions that are needed to actualize their 
purpose, but it must also facilitate their access to content and functions. For example, in applying representation theory to the context of effective use, Burton-Jones \& Grange (2013) observed that a system's surface (e.g., output display options for a dashboard) and physical structures (e.g., the size of the screen) enable access to its deep structures (i.e., the state of a domain that the system aims to represent). Similarly, Hartson's (2003) theory of affordances suggests that, in order to leverage an IT to reach one's goals, one must be able to first sense and physically interact with it. Applied to the present study's organizational intranet context, this implies that because navigation involves crossing a website's information space, assessments of navigational aspects are also likely to partly rely on how effectively the information is laid out on the different pages that are being traversed, in addition to the website' visual appearance. In other words, a user's interactions with, and assessments of Page Layout Quality features are also likely to influence the formation of her/his beliefs about the effectiveness of a website's navigation system. Hence:

H3: Visual Quality will positively influence Navigation Quality (H3a) and Page Layout Quality (H3b). H4: Page Layout Quality will positively influence Navigation Quality.

\section{Relationships Between Information Quality, System Quality, PEOU, PU, and Attitude}

Past research has extensively justified and empirically supported the relationships illustrated in the dashed box of Figure 2 (e.g., Davis, 1989; Taylor \& Todd, 1995; Wixom \& Todd, 2005), hence they are only briefly discussed here. First, Attitude, i.e., users' general evaluation towards using a website, is expected to be positively influenced by PU, i.e., beliefs about the extent to which using a website enhances task performance, and PEOU, i.e., beliefs about the extent to which using a website is free of effort, and PEOU is expected to positively influence PU. Second, Information Quality, i.e., users' beliefs about the quality of the informational output generated by a website, and System Quality, i.e., users' beliefs about the quality of a website's functioning, are expected to be positively related to PU and PEOU (Wixom \& Todd, 2005). Third, PEOU and System Quality are expected to positively influence PU.

\section{METHOD}

Data for testing the proposed research model was collected via an online survey of intranet users in three organizations that agreed to participate in the study. As intranet websites are prevalent and important for organizations (Alavi \& Leidner, 2001; Barnes \& Vidgen, 2012), they were considered to provide a relevant and appropriate context for testing the proposed model as users' evaluations of intranet websites are likely to be based on their repeated experiences with the system for work purposes, and thus to be highly reliable. One organization among the three that took part in the study was a branch in a government ministry (labeled MINIS). It had a decentralized technological environment, with an intranet website that was mostly informational and with limited transactional functionalities. PRIV was a private organization with a large number of employees who were spread across the country. First implemented in 1994, the corporate intranet had been improved with several redesigns and was more sophisticated than the one at MINIS. Finally, FEDE was a federal government organization with several hundred employees and had an essentially informational intranet. Overall, the three settings covered diverse organizational characteristics (type: public vs. private; size: medium to large), as well as various intranet characteristics (static and informational to dynamic and transactional). This diversity enabled the study to access a wide range of user responses which suggest that a variety of usage experiences were obtained, which in turn helped provide a more complete and representative set of variations and covariations among the study variables.

The approach that was used for sampling participants was adjusted to the characteristics and constraints of each site. At MINIS, an invitation to respond to the survey was posted for two weeks 
on the intranet website's home page because the organization's policies did not allow the researchers to directly contact their employees. Overall, 97 connections were made to the server that hosted the online survey, and 27 usable questionnaires were obtained from the 28 that were completed. At PRIV, e-mail invitations were sent to a random selection of employees in each local division. No message was posted on the intranet's home page due to organizational restrictions, and the survey yielded 84 usable questionnaires (from 107 PRIV employees who completed the survey out of 142 who accessed it). At FEDE, a message was displayed on the intranet website's home page and an e-mail was sent to all employees, inviting them to participate in the study, and yielded 48 usable questionnaires (from 57 individuals who completed the survey out of 106 who accessed it).

Scales for measuring Attitude, PEOU, PU, Information Quality, and System Quality were adapted from past studies of IT acceptance and success (Davis, 1989; Nelson et al., 2005). Scales for measuring the three design quality constructs were developed with reflective items that captured the essence of the constructs' definition. As data collection from organizational users could only be made during their work hours, the study questionnaire was kept as short as possible by limiting all measurement scales to two items. A key challenge in survey design is to optimize the number of items and the amount of information they convey without threatening measurement validity (Drolet $\&$ Morrison, 2001). As the number of items that are needed to measure a construct is highly contingent on the construct's broadness (Bearden \& Netemeyer, 1999), and the constructs of the present study were fairly narrow, two-item scales were considered to be adequate (Bergkvist \& Rossiter, 2007; Hair, Ringle, \& Sarstedt, 2011). The survey instrument and its item loadings are provided in Appendix A. As can be seen, both positively and negatively worded items were used in order to avoid patterns of consistent responses that would be based on format rather than the measured traits, as well as to help identify and discard speeders, i.e., respondents who tend not to provide thoughtful answers (Nunnally, 1967; Yamaguchi, 1997).

Overall, all study respondents were highly familiar with the web in general, as well as with their respective intranets (Table 1). Their familiarity with the web is likely to have provided them with a general design benchmark that is likely to have been useful for helping respondents to more accurately assess their intranets. Their average age varied across the three organizations with FEDE's respondents being younger than those at MINIS, and PRIV's respondents being more balanced in that regard. Gender, age, usage frequency, and familiarity with the web in general, as well as their familiarity with the intranet website were included as control variables.

\section{DATA ANALYSES AND RESULTS}

The research model of Figure 2 was analyzed with SmartPLS 3.0 (Ringle, Wende \& Becker, 2015), which enables testing both the measurement and the structural model (Wixom \& Watson, 2001) while meeting sample size requirements (Henseler et al., 2014). PLS structural equation modeling (SEM) aims to maximize the explained variance in the dependent latent constructs while involving less stringent assumptions (e.g., about data normality) and sample size requirement than covariancebased SEM (Hair, Hult, Ringle, \& Sarstedt, 2017; Hair et al., 2011).

\section{Testing the Measurement Model}

As shown in Table 2, the composite reliability (CR) and average variance extracted (AVE) were above the 0.70 and 0.50 thresholds, respectively, and the square root of their AVE was superior to interconstruct inter-correlations. Overall, these results provide support for the convergent and discriminant validity of the study constructs (Fornell \& Larcker, 1981).

As the study sample contained data that was collected from respondents who worked in three different organizations, a check of measurement invariance between the three groups was made by using the SmartPLS 3.0 measurement invariance test for multi-group analysis. The results are provided 
Table 1. Respondent profiles

\begin{tabular}{|l|l|l|l|}
\hline & \multicolumn{1}{|c|}{ MINIS [N=27] } & \multicolumn{1}{|c|}{ PRIV [N=84] } & \multicolumn{1}{|c|}{ FEDE [N=48] } \\
\hline Gender & & & \\
\hline Female & $57.7 \%$ & $34.5 \%$ & $54.3 \%$ \\
\hline Male & $42.3 \%$ & $65.5 \%$ & $45.7 \%$ \\
\hline Age & & & \\
\hline $20-30$ & $11.5 \%$ & $12 \%$ & $38.3 \%$ \\
\hline $31-40$ & $23.1 \%$ & $21.7 \%$ & $38.3 \%$ \\
\hline $41-50$ & $23.1 \%$ & $36.1 \%$ & $17 \%$ \\
\hline $51-60$ & $42.3 \%$ & $28.9 \%$ & $6.4 \%$ \\
\hline Usage frequency & & & \\
\hline Times a day & $25.9 \%$ & $79.8 \%$ & $55.3 \%$ \\
\hline Once a day & $22.3 \%$ & $16.6 \%$ & $31.9 \%$ \\
\hline Once a week & $44.4 \%$ & $3.6 \%$ & $8.5 \%$ \\
\hline Once a month & $7.4 \%$ & - & $4.3 \%$ \\
\hline Familiarity (Web) & & & \\
\hline Little & - & $1.2 \%$ & - \\
\hline Fairly & $26.9 \%$ & $27.4 \%$ & $10.6 \%$ \\
\hline Very & $34.5 \%$ & $46.4 \%$ & $51.1 \%$ \\
\hline Extremely & $38.6 \%$ & $25 \%$ & $38.3 \%$ \\
\hline Familiarity (Intranet) & & - & $25.6 \%$ \\
\hline Little & $7.7 \%$ & $10.8 \%$ & $12.8 \%$ \\
\hline Fairly & $44.3 \%$ & & $59.6 \%$ \\
\hline Very & $32.6 \%$ & & \\
\hline Extremely & $15.4 \%$ & & \\
\hline & & & \\
\hline
\end{tabular}

in Appendix B and indicated that no significant differences existed between any of the compared pairs of loadings.

In addition, two different approaches were used to test for method bias. The first test involved adding a first-order latent method factor to the model with all construct items modeled as indicators of the method factor (e.g., Liang, Saraf, Hu \& Xue, 2007; Podsakoff, MacKenzie, Lee \& Podsakoff, 2003). The second test involved the use of marker variables as a means to control for common method variance (Rönkkö \& Ylitalo, 2011). The results of both approaches are provided in Appendix C, and indicate that common method bias is not likely to have influenced the results of the present study.

\section{Testing the Structural Model}

The results obtained for the structural model are shown in Figure 3. As can be seen, Page Layout Quality $(\beta=.19, \mathrm{p}>.05)$, Navigation Quality $(\beta=.39, \mathrm{p}<.001)$, and Visual Quality $(\beta=.25, \mathrm{p}$ $<.001$ ), significantly influenced System Quality, explaining $50.2 \%$ of its variance, and supporting H1a, H1b, and H1c.

Moreover, all design quality constructs positively influenced Information Quality, and explained $54.1 \%$ of its variance, supporting $\mathrm{H} 2 \mathrm{a}, \mathrm{H} 2 \mathrm{~b}$, and $\mathrm{H} 2 \mathrm{c}$ : Page Layout Quality $(\beta=.38, \mathrm{p}<.001)$, 
Table 2. Assessing construct reliability and validity

\begin{tabular}{|l|l|l|l|l|l|l|l|l|}
\hline & \multicolumn{1}{|c|}{ IQ } & SQ & \multicolumn{1}{c|}{ NQ } & PLQ & VQ & PEOU & PU & ATT \\
\hline Information Quality (IQ) & $\mathbf{. 8 9}$ & & & & & & & \\
\hline System Quality (SQ) & .70 & $\mathbf{. 8 3}$ & & & & & & \\
\hline Navigation Quality (ND) & .64 & .61 & $\mathbf{. 8 5}$ & & & & & \\
\hline Page Layout Quality (PLQ) & .65 & .56 & .59 & $\mathbf{. 8 8}$ & & & & \\
\hline Visual Quality (VD) & .60 & .59 & .59 & .63 & $\mathbf{. 9 2}$ & & & \\
\hline Perceived Ease of Use (PEOU) & .63 & .53 & .67 & .55 & .55 & $\mathbf{. 8 6}$ & & \\
\hline Perceived Usefulness (PU) & .71 & .47 & .61 & .56 & .53 & .63 & $\mathbf{. 8 4}$ & \\
\hline Attitude (ATT) & .73 & .63 & .75 & .62 & .66 & .72 & .70 & $\mathbf{. 8 9}$ \\
\hline Composite Reliability (>.70) & .88 & .81 & .84 & .87 & .91 & .85 & .83 & .89 \\
\hline $\begin{array}{l}\text { Average Variance Extracted } \\
(>.50)\end{array}$ & .79 & .69 & .72 & .78 & .84 & .74 & .70 & .79 \\
\hline
\end{tabular}

Keys: Bold numbers in the diagonal indicate the square root of constructs' average variance extracted (AVE). The other numbers, except those on the two last rows, represent correlations between constructs.

\section{Figure 3. Testing the research model}

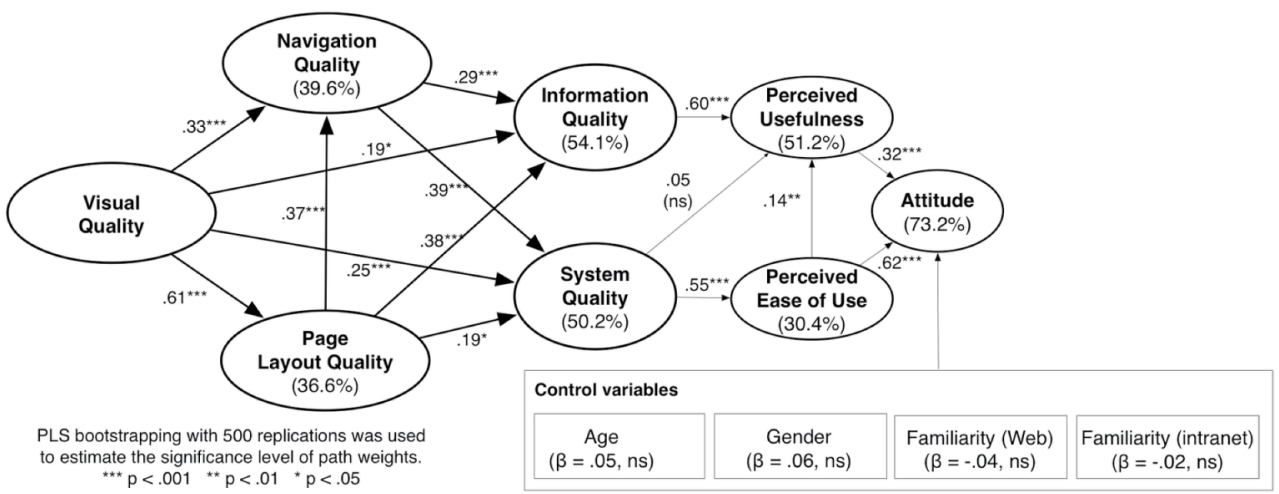

Navigation Quality $(\beta=.29, \mathrm{p}<.001)$, and Visual Quality $(\beta=.19, \mathrm{p}<.05)$. Overall, Visual Quality significantly influenced both Navigation Quality $(\beta=.33, \mathrm{p}<.001)$, and Page Layout Quality $(\beta$ $=.61, \mathrm{p}<.001)$, supporting $\mathrm{H} 3 \mathrm{a}$ and $\mathrm{H} 3 \mathrm{~b}$. Page Layout Quality was also significantly related to Navigation Quality $(\beta=.37, \mathrm{p}<.001)$, supporting $\mathrm{H} 4$.

To further analyze the indirect effects of the research model, mediation analyses were also done. First, the indirect effect of Visual Quality on Navigation Quality (i.e., via Page Layout Quality) was examined and was found to be significant $(\beta=.22, \mathrm{p}<.001)$. Second, the indirect effects involved in predicting Information Quality and System Quality were examined. In the research model, Information Quality has three direct influences (the three design quality constructs) and three indirect influences. The indirect influence of Page Layout Quality via Navigation Quality was significant $(\beta=.11, \mathrm{p}<$ $.005)$. The two indirect influences of Visual Quality were also significant: via Navigation Quality ( $\beta$ $=0.10, \mathrm{p}<0.05)$, and via Page Layout Quality $(\beta=.23, \mathrm{p}<.001)$. Further, in the research model, System Quality has three direct and three indirect influences. Page Layout Quality's influence via Navigation Quality was significant $(\beta=.15, \mathrm{p}<.005)$. The two indirect influences from Visual 
Quality were also significant: via Navigation Quality $(\beta=.13, \mathrm{p}<.005)$, and via Page Layout Quality $(\beta=.12, \mathrm{p}<.05)$.

Finally, consistent with the findings of past research, both PU $(\beta=.32, p<.001)$ and PEOU $(\beta$ $=.62, \mathrm{p}<.001)$ were observed to significantly and positively influence Attitude, explaining $73.2 \%$ of its variance. In addition, PEOU was positively related to PU $(\beta=.14, \mathrm{p}<.05)$, and Information Quality and System Quality positively influenced both PU $(\beta=.60, \mathrm{p}<.001)$ and PEOU $(\beta=.55, \mathrm{p}$ $<0.001)$, respectively. The relationship between System Quality and Perceived Usefulness was not significant, which is not very surprising due to the fact that the link between these two constructs was mediated by two constructs—information and system satisfaction-in Wixom and Todd (2005). Table 3 provides a summary of the observed results.

\section{DISCUSSION}

The goal of the present study was to examine the nature and role of factors that represent evaluations of relatively specific design aspects of IT in organizational intranet contexts in order to help move research beyond the consideration of user experience constructs that capture relatively broad and high-level evaluations, such as satisfaction, usefulness, and ease of use. The results of the study that assessed individual users' evaluations of their experience in using their organizational intranet websites provided strong support for the validity of the research model's causal chain. As such, a key theoretical contribution of the present study is that it provides a step towards closing an important gap in the IT literature where "...current theoretical perspectives on individual acceptance are notably weak in providing prescriptive guidance to designers." (Venkatesh et al., 2003, p. 470). As several researchers have also noted, researchers need to "...drill down into what design characteristics influence what specific aspects of perceived usefulness and perceived ease of use..." (Venkatesh \& Bala, 2008, p. 294), “...go beyond general constructs (such as user satisfaction, usefulness, or relative advantage) to more detailed constructs (such as data quality, locatability, systems reliability, etc.)..." (Goodhue \& Thompson, 1995, p. 230), and seek “...technology-specific antecedents to the general construct [e.g., usefulness]" (Evermann \& Tate, 2009, p. 3). The present study provides a contribution in this regard as it identifies three key design quality beliefs, explaining how they form and relate to beliefs that have been examined in the literature, by building on a fundamental theoretical idea: that users' beliefs can be viewed as forming a causal continuum from descriptive (resulting from direct observation) to inferential (derived from other beliefs), and that such beliefs tend to be causally related when they tap into nested properties (Fishbein \& Ajzen, 1975).

Table 3. Summary of hypothesis testing results

\begin{tabular}{|l|l|}
\hline \multicolumn{1}{|c|}{ Hypotheses } & \multicolumn{1}{c|}{ Supported? } \\
\hline H1a: Page Layout Quality will positively influence System Quality & Yes \\
\hline H1b: Navigation Quality will positively influence System Quality & Yes \\
\hline H1c: Visual Quality will positively influence System Quality & Yes \\
\hline H2a: Page Layout Quality will positively influence Information Quality. & Yes \\
\hline H2b: Navigation Quality will positively influence Information Quality. & Yes \\
\hline H2c: Visual Quality will positively influence Information Quality. & Yes \\
\hline H3a: Visual Quality will positively influence Navigation Quality & Yes \\
\hline H3b: Visual Quality will positively influence Page Layout Quality & Yes \\
\hline H4: Page Layout Quality will positively influence Navigation Quality & Yes \\
\hline
\end{tabular}


By building on and expanding an integrative framework (Wixom \& Todd, 2005), and by drawing on and adapting Cyr's (2008; 2014) design ontology, the present study identified three categories of beliefs regarding a website's design characteristics (i.e., quality of its navigation, page layout, and visual elements), and linked them to IT acceptance constructs. As such, the present study's research model and its results help bridge the existing gaps between IT artifact design and IT acceptance research.

Several key insights about the role of the three design quality constructs can be noted. Navigation Quality and Page Layout Quality were found to directly influence both Information Quality and System Quality. Moreover, Page Layout Quality had an indirect influence on Information Quality and System Quality via Navigation Quality. In addition, Visual Quality was not only a significant direct driver of both Information Quality and System quality (with a stronger direct effect on the latter), it also influenced them indirectly via Page Layout Quality and Navigation Quality. This influence of Visual Quality, which taps into users' evaluation of a website's visual appearance, needs to be emphasized because it is a domain that is rarely taken into account in the context of IT acceptance studies (Vance et al., 2008).

It is also important to note that, from a general perspective, the present study can be viewed as being situated between two categories of work that exist in the literature: a) highly design-focused work that is also very context-dependent and grounded in practice (e.g., Hoehle \& Venkatesh, 2015), and b) research that is highly generalizable, but less design-prescriptive (e.g., theories of user acceptance). In essence, the different possible approaches that are possible for examining IT design and user experiences/evaluations (all valuable in their own unique ways) are summarized in Table 4. The present study focused on developing a model that was anchored in a strong theoretical foundation, i.e., TRA, so that it could provide a strong link to past research while extending it with a design perspective. Moreover, it should also be noted that, compared to other studies (e.g., Hoehle \& Venkatesh, 2015; Hong et al., 2001), the present study is more context-agnostic because the three design factors it proposed and examined can be applied to any kind of website (e.g., intranet, e-commerce, e-government).

\section{PRACTICAL IMPLICATIONS}

Based on the present study's findings, several suggestions can be made for practitioners. First, the study findings suggest that the three design characteristics it examined are likely to significantly influence the many users' beliefs about an organizational intranet and its ability to offer quality content and delivery mechanisms, which might be applicable to many other IT as well. Second, as summarized in Table 5, the findings of the present study encourage and helps practitioners to monitor and diagnose salient user evaluation factors, as well as communicate about them with users. The present study's survey instrument can also be helpful to practitioners who can use it as a diagnostic tool for assessing general user evaluation factors and/or the three design factors, depending on the level of granularity they are interested in. For example, a project manager is likely to be able to better justify investing

Table 4. Different ways to contribute to user experience research that offers design insights

\begin{tabular}{|l|l|l|}
\hline & \multicolumn{1}{|c|}{$\begin{array}{c}\text { By Identifying Highly Context- } \\
\text { Specific Design Factors }\end{array}$} & \multicolumn{1}{|c|}{$\begin{array}{c}\text { By Identifying More Context-Agnostic } \\
\text { Design Factors }\end{array}$} \\
\hline $\begin{array}{l}\text { The proposed model is } \\
\text { informed by practitioner } \\
\text { guidelines }\end{array}$ & $\begin{array}{l}\text { For example, using Apple design } \\
\text { guidelines in the context of mobile } \\
\text { apps (Hoehle \& Venkatesh, 2015). }\end{array}$ & $\begin{array}{l}\text { For example, identifying website usability } \\
\text { indicators based on Microsoft Usability } \\
\text { Guidelines (Agarwal and Venkatesh 2002). }\end{array}$ \\
\hline $\begin{array}{l}\text { The proposed model is } \\
\text { informed by theory and } \\
\text { existing research }\end{array}$ & $\begin{array}{l}\text { For example, in the context of digital } \\
\text { libraries, using criteria from the library } \\
\text { science literature (Hong et al., 2001). }\end{array}$ & $\begin{array}{l}\text { For example, the present study, which } \\
\text { specifies three key design factors for websites } \\
\text { based on TRA. }\end{array}$ \\
\hline
\end{tabular}


more resources in graphic design by using the study's measures to assess users' ratings of the Visual Quality of a website in question and thus provide evidence of their poor quality. In addition, designers could use the questionnaire items as a checklist of the important elements they need to be aware of and carefully assess. The three design dimensions can also be used as a framework that can help communication among team members and with clients, as well as providing a common background and language for stakeholders. Moreover, project management offices can also use the proposed framework for developing competency profiles and to build a common understanding of the role of design quality in user experience and IT acceptance.

\section{LIMITATIONS AND FUTURE RESEARCH}

One limitation of the present study is that its cross-sectional survey method does not provide as strong an approach for testing causal relationships as some other approaches, such as surveys that cover multiple time periods (e.g., measuring Visual Quality at $t_{1}$, Page Layout Quality at $t_{2}$, Navigation Quality at $\mathrm{t}_{3}$, and Information and System Quality at $\mathrm{t}_{4}$ ), or experiments that can test the influence of specific design aspects on user evaluations of Information and System Quality.

Also, while the proposed design quality constructs tap into properties that are specific to how websites are designed (i.e., their navigation system, page layout, visual appearance), they were operationalized by capturing relatively general assessments (e.g., "The visual appearance of is of high quality"). This choice was made due to the exploratory nature of the present study. The main focus of the present study was on proposing and providing an initial empirical assessment of its research model and measures, and on making the latter easily applicable to other website settings. Clearly, identifying and measuring more specific guidelines than the ones used in the present study would certainly be useful (e.g., how can the quality of a website' visual appearance be improved?), and can be achieved in future studies by extending the present study's research model to incorporate into it more granular criteria. For example, one approach would be to conceptualize and operationalize the three design factors via formative constructs by using the general items proposed here as the reflective indicators of the three constructs, and by developing formative items based on descriptive design criteria (e.g., via the use of MIMIC models Diamantopoulos \& Winklhofer, 2001; Kim, Shin $\&$ Grover, 2010). Researchers could interview users in order to identify potential sub-dimensions of the three design quality constructs, which can help researchers develop formative items, which in turn is likely to be useful for better understanding the design characteristics that are salient and instrumental to users' assessments of website quality.

Another limitation of the present study is that it did not consider function-specific design aspects due to the fact that they tend to be highly contingent upon context. As such, function-specific design aspects are difficult to incorporate into studies that aim to derive general design quality beliefs, which was a key objective of the present study. Some researchers have offered domain-specific contributions

Table 5. Practical implications for web design projects

\begin{tabular}{|l|l|}
\hline \multicolumn{1}{|c|}{ How Practitioners Can Exploit the Present Research } & \multicolumn{1}{c|}{ Benefits of Practitioners' Actions } \\
\hline $\begin{array}{l}\text { By using the questionnaire (design quality and acceptance } \\
\text { constructs) to assess users' evaluation of the system. }\end{array}$ & $\begin{array}{l}\text { Help decide whether a new design is required } \\
\text { and prioritize resource allocation. }\end{array}$ \\
\hline $\begin{array}{l}\text { By using the proposed model to support external and internal } \\
\text { communications, and the model and survey items to informally } \\
\text { assess design effectiveness. }\end{array}$ & $\begin{array}{l}\text { Help build common knowledge on the design } \\
\text { process and monitor the quality of the design } \\
\text { team's deliverables. }\end{array}$ \\
\hline By using the questionnaire to measure design quality constructs. & Help assess design adjustments. \\
\hline $\begin{array}{l}\text { By using the questionnaire to measure attitude, PEOU, and PU, for a } \\
\text { quick evaluation of the new system. }\end{array}$ & $\begin{array}{l}\text { Help monitor user experience on a regular basis } \\
\text { and assess if adjustments are needed. }\end{array}$ \\
\hline
\end{tabular}


for websites on e-commerce (Cenfetelli et al., 2008) and e-government (Tan, Benbasat, \& Cenfetelli, 2013), and future research can contribute to these efforts by considering both function-specific and function-agnostic elements, and by examining their influence on user attitudes toward websites.

Finally, the present study focused on design-specific constructs and their influence on other evaluation criteria that are part of the user acceptance nomological network (e.g., information quality and system quality). Future research could extend this perspective by examining how the three design quality constructs relate to other important markers or drivers of successful user-IT interactions. For example, prior work suggests that web quality is instrumental to users' evaluation of an organization's online image (Walczak \& Gregg, 2009) as well as to the level of trust users attribute to a particular website or to the organization in charge of it (Gregg \& Walczak, 2010). In such studies, web quality tends to be considered at a fairly high level of abstraction, encompassing aspects of both content and its presentation. As such, an interesting extension of the present study can be to investigate how and why the more specific design quality constructs influence these other important outcomes.

\section{CONCLUSION}

Given the importance of users' experience when interacting with ITs and their evaluations, a substantial amount of research has leveraged perception-based theories in order to explain how and why users decide to use certain ITs and not others. An important gap that remains in this body of work is a lack of theorizing regarding the influence of more granular, and hence more actionable design elements on user acceptance, which can help provide helpful guidelines to practitioners as well. To address this gap, the present study proposed and tested a research model that extends past research by identifying three design quality beliefs as having an important influence on a website's Information Quality and System Quality. Navigation Quality, Page Layout Quality, and Visual Quality tap into detailed design characteristics of websites and enable researchers and practitioners to go beyond user evaluations that only capture broad indicators, such as satisfaction, usefulness, and ease of use, enabling the specification and monitoring of criteria that are useful from a design standpoint. 


\section{REFERENCES}

Agarwal, R., \& Venkatesh, V. (2002). Assessing a firm's web presence: a heuristic evaluation procedure for the measurement of usability. Information Systems Research, 13(2), 168-186. doi:10.1287/isre.13.2.168.84

Al-Natour, S., \& Benbasat, I. (2009). The adoption and use of IT artifacts: A new interaction-centric model for the study of user-artifact relationships. Journal of the Association for Information Systems, 10(9), 661-685. doi: $10.17705 / 1$ jais.00208

Alavi, M., \& Leidner, D. E. (2001). Review: Knowledge management and knowledge management systems: Conceptual foundations and research issues. Management Information Systems Quarterly, 25(1), $107-136$. doi: $10.2307 / 3250961$

Barnes, S. J., \& Vidgen, R. (2001). An evaluation of cyber-bookshops: The WebQual method. International Journal of Electronic Commerce, 6(1), 11-30. doi:10.1080/10864415.2001.11044225

Barnes, S. J., \& Vidgen, R. (2012). User acceptance and corporate intranet quality: An evaluation with iQual. Information \& Management, 49(3-4), 164-170. doi:10.1016/j.im.2012.02.002

Barnes, S. J., \& Vidgen, R. T. (2002). An Integrative Approach to the Assessment of E-Commerce Quality. Journal of Electronic Commerce Research, 3(3), 114-127.

Bearden, W. O., \& Netemeyer, R. G. (1999). Handbook of marketing scales: Multi-item measures for marketing and consumer behavior research. Sage. doi:10.4135/9781412984379

Benbasat, I., \& Barki, H. (2007). Quo Vadis, TAM? Journal of the Association for Information Systems, 8(4), 211-218. doi:10.17705/1jais.00126

Bergkvist, L., \& Rossiter, J. R. (2007). The Predictive Validity of Multiple-Item Versus Single-Item Measures of the Same Constructs. JMR, Journal of Marketing Research, 44(2), 175-184. doi:10.1509/jmkr.44.2.175

Burton-Jones, A., \& Grange, C. (2013). From use to effective use: A representation theory perspective. Information Systems Research, 24(3), 632-658. doi:10.1287/isre.1120.0444

Cenfetelli, R. T., Benbasat, I., \& Al-Natour, S. (2008). Addressing the what and how of online services: positioning supporting-services functionality and service quality for business-to-consumer success. Information Systems Research, 19(2), 161-181. doi:10.1287/isre.1070.0163

Cyr, D. (2008). Modeling web site design across cultures: Relationships to trust, satisfaction, and e-loyalty. Journal of Management Information Systems, 24(4), 47-72. doi:10.2753/MIS0742-1222240402

Cyr, D. (2014). Return visits: A review of how web site design can engender visitor loyalty. Journal of Information Technology, 29(1), 1-26. doi:10.1057/jit.2013.25

Davis, F. D. (1989). Perceived usefulness, perceived ease of use, and user acceptance of information technology. Management Information Systems Quarterly, 13(3), 319-340. doi:10.2307/249008

Davis, F. D. (1993). User acceptance of information technology: System characteristics, user perceptions and behavioral impacts. International Journal of Man-Machine Studies, 38(3), 475-487. doi:10.1006/imms.1993.1022

Davis, F. D., Bagozzi, R. P., \& Warshaw, P. R. (1989). User acceptance of computer technology: A comparison of two theoretical models. Management Science, 35(8), 982-1003. doi:10.1287/mnsc.35.8.982

DeLone, W. H., \& McLean, E. R. (1992). Information Systems Success: the quest for the dependent variable. Information Systems Research, 3(1), 60-95. doi:10.1287/isre.3.1.60

DeLone, W. H., \& McLean, E. R. (2003). The DeLone and McLean model of information systems success: A tenyear update. Journal of Management Information Systems, 19(4), 9-30. doi:10.1080/07421222.2003.11045748

Diamantopoulos, A., \& Winklhofer, H. M. (2001). Index construction with formative indicators: An alternative to scale development. JMR, Journal of Marketing Research, 38(2), 269-277. doi:10.1509/jmkr.38.2.269.18845

Drolet, A. L., \& Morrison, D. G. (2001). Do we really need multiple-item measures in service research? Journal of Service Research, 3(3), 196-204. doi:10.1177/109467050133001 
Evermann, J., \& Tate, M. (2009). Constructs in the Mist: The Lost World of the IT Artifact. In Proceedings of the 30th International Conference of Information Systems (ICIS). Phoenix, AZ.

Fishbein, M., \& Ajzen, I. (1975). Belief, attitude, intention and behavior: An introduction to theory and research. Reading, MA: Addison-Wesley Reading.

Fornell, C., \& Larcker, D. F. (1981). Evaluating structural equation models with unobservable variables and measurement error. JMR, Journal of Marketing Research, 18(1), 39-50. doi:10.2307/3151312

Garrett, J. J. (2002). The elements of user experience: User-centered design for the web. New York, NY: New Riders Publishing in conjunction with the American Institute of Graphic Arts.

Goodhue, D. L., \& Thompson, R. L. (1995). Task-technology fit and individual performance. Management Information Systems Quarterly, 19(2), 213-236. doi:10.2307/249689

Gregg, D. G., \& Walczak, S. (2010). The relationship between website quality, trust and price premiums at online auctions. Electronic Commerce Research, 10(1), 1-25. doi:10.1007/s10660-010-9044-2

Hair, J., Ringle, C., \& Sarstedt, M. (2011). PLS-SEM: Indeed a Silver Bullet. Journal of Marketing Theory and Practice, 19(2), 139-151. doi:10.2753/MTP1069-6679190202

Hair, J. F., Hult, G. T. M., Ringle, C., \& Sarstedt, M. (2017). A Primer on Partial Least Squares Structural Equation Modeling (PLS-SEM) (2nd ed.). SAGE Publications.

Hartson, H. R. (2003). Cognitive, physical, sensory, and functional affordances in interaction design. Behaviour \& Information Technology, 22(5), 315-338. doi:10.1080/01449290310001592587

Henseler, J., Dijkstra, T. K., Sarstedt, M., Ringle, C. M., Diamantopoulos, A., Straub, D. W., \& Calantone, R. J. et al. (2014). Common beliefs and reality about PLS comments on Rönkkö and Evermann (2013). Organizational Research Methods, 1-28. doi:10.1177/1094428114526928

Hoehle, H., \& Venkatesh, V. (2015). Mobile application usability: Conceptualization and instrument development. Management Information Systems Quarterly, 39(2), 435-472. doi:10.25300/MISQ/2015/39.2.08

Hong, W., Thong, J. Y. L., Wong, W.-M., \& Tam, K.-Y. (2001). Determinants of user acceptance of digital libraries: An empirical examination of individual differences and system characteristics. Journal of Management Information Systems, 18(3), 97-124. doi:10.1080/07421222.2002.11045692

Kim, G., Shin, B., \& Grover, V. (2010). Investigating two contradictory views of formative measurement in information systems research. Management Information Systems Quarterly, 34(2), 345-A5. doi:10.2307/20721431

Lavie, T., \& Tractinsky, N. (2004). Assessing dimensions of perceived visual aesthetics of web sites. International Journal of Human-Computer Studies, 60(3), 269-298. doi:10.1016/j.ijhcs.2003.09.002

Lee, Y., Kozar, K. A., \& Larsen, K. R. T. (2003). The Technology Acceptance Model: Past, Present, and Future. Communications of AIS, (12), 752-780.

Liang, H., Saraf, N., Hu, Q., \& Xue, Y. (2007). Assimilation of enterprise systems: The effect of institutional pressures and the mediating role of top management. Management Information Systems Quarterly, 31(1), 59-87. doi: $10.2307 / 25148781$

Loiacono, E., Watson, R., \& Goodhue, D. (2007). WebQual: An instrument for consumer evaluation of web sites. International Journal of Electronic Commerce, 11(3), 51-87. doi:10.2753/JEC1086-4415110302

McKinney, V., Yoon, K., \& Zahedi, F. M. (2002). The Measurement of Web-Customer Satisfaction: An Expectation and Disconfirmation Approach. Information Systems Research, 13(3), 296-315. doi:10.1287/ isre.13.3.296.76

Morville, P., \& Rosenfeld, L. (2006). Information Architecture for the World Wide Web. O'Reilly Media. Retrieved from http://shop.oreilly.com/product/9780596527341.do

Nelson, R. R., Todd, P. A., \& Wixom, B. H. (2005). Antecedents of Information and System Quality: An Empirical Examination Within the Context of Data Warehousing. Journal of Management Information Systems, 21(4), 199-235. doi:10.1080/07421222.2005.11045823

Nunnally, J. C. (1967). Psychometric Theory. New York, NY: McGraw-Hill. 
Palmer, J. W. (2002). Web site usability, design, and performance metrics. Information Systems Research, 13(2), 151-167. doi:10.1287/isre.13.2.151.88

Petter, S., Delone, W., \& McLean, E. (2008). Measuring information systems success: Models, dimensions, measures, and interrelationships. European Journal of Information Systems, 17(3), 236-263. doi:10.1057/ ejis.2008.15

Petter, S., DeLone, W., \& McLean, E. R. (2013). Information systems success: The quest for the independent variables. Journal of Management Information Systems, 29(4), 7-62. doi:10.2753/MIS0742-1222290401

Podsakoff, P., MacKenzie, S., Lee, J., \& Podsakoff, N. (2003). Common method biases in behavioral research: A critical review of the literature and recommended remedies. The Journal of Applied Psychology, 88(5), 879-903. doi:10.1037/0021-9010.88.5.879 PMID:14516251

Rai, A., Lang, S. S., \& Welker, R. B. (2002). Assessing the validity of IS success models: An empirical test and theoretical analysis. Information Systems Research, 13(1), 50-69. doi:10.1287/isre.13.1.50.96

Ringle, C., Wende, S., \& Becker, J.-M. (2015). SmartPLS 3. Bönningstedt: SmartPLS. Retrieved from http:// www.smartpls.com

Rönkkö, M., \& Ylitalo, J. (2011). PLS marker variable approach to diagnosing and controlling for method variance. Presented at the International Conference of Information Systems.

Seddon, P. B. (1997). A Respecification and Extension of the DeLone and McLean Model of IS Success. Information Systems Research, 8(3), 240-253. doi:10.1287/isre.8.3.240

Shahizan, H., \& Li, F. (2005). Evaluating the usability and content usefulness of web sites: A benchmarking approach. Journal of Electronic Commerce in Organizations, 3(2), 46-67. doi:10.4018/jeco.2005040104

Sonderegger, A., \& Sauer, J. (2010). The influence of design aesthetics in usability testing: Effects on user performance and perceived usability. Applied Ergonomics, 41(3), 403-410. doi:10.1016/j.apergo.2009.09.002 PMID:19892317

Tan, C.-W., \& Benbasat, I. (2009). IT mediated customer services in e-government: A citizen's perspective. Communications of the AIS, 24(1), 175-198.

Tan, C.-W., Benbasat, I., \& Cenfetelli, R. T. (2013). IT-mediated customer service content and delivery in electronic governments: An empirical investigation of the antecedents of service quality. Management Information Systems Quarterly, 37(1), 77-109. doi:10.25300/MISQ/2013/37.1.04

Tarafdar, M., \& Zhang, J. (2005). Analyzing the Influence of web site design parameters on web site usability. Information Resources Management Journal, 18(4), 62-80. doi:10.4018/irmj.2005100104

Taylor, S., \& Todd, P. (1995). Understanding information Technology Usage: A Test of Competing Models. Information Systems Research, 6(2), 144-176. doi:10.1287/isre.6.2.144

Toms, E. G. (2002). Information interaction: Providing a framework for information architecture. Journal of the American Society for Information Science and Technology, 53(10), 855-862. doi:10.1002/asi.10094

Tractinsky, N. (2018). The usability construct: A dead end? Human-Computer Interaction, 33(2), 131-177. do i: $10.1080 / 07370024.2017 .1298038$

Tractinsky, N., Katz, A. S., \& Ikar, D. (2000). What is beautiful is usable. Interacting with Computers, 13(2), 127-145. doi:10.1016/S0953-5438(00)00031-X

Vance, A., Elie-Dit-Cosaque, C., \& Straub, D. W. (2008). Examining trust in information technology artifacts: The effects of system quality and culture. Journal of MIS, 24(4), 73-100. doi:10.2753/MIS0742-1222240403

Venkatesh, V., \& Agarwal, R. (2006). Turning visitors into customers: A usability-centric perspective on purchase behavior in electronic channels. Management Science, 52(3), 367-382. doi:10.1287/mnsc.1050.0442

Venkatesh, V., \& Bala, H. (2008). Technology acceptance model 3 and a research agenda on interventions. Decision Sciences, 39(2), 273-315. doi:10.1111/j.1540-5915.2008.00192.x

Venkatesh, V., Davis, F. D., \& Morris, M. G. (2007). Dead Or Alive? The development, trajectory and future of technology adoption research. Journal of the AIS, 8(4), 268-286. 
Venkatesh, V., Morris, M. G., Davis, G. B., \& Davis, F. D. (2003). User acceptance of information technology: toward a unified view. Management Information Systems Quarterly, 27(3), 425-478. doi:10.2307/30036540

Venkatesh, V., \& Venkataraman, R. (2006). Web and wireless site usability: understanding differences and modeling use. Management Information Systems Quarterly, 30(1), 181-205. doi:10.2307/25148723

Walczak, S., \& Gregg, D. G. (2009). Factors influencing corporate online identity: A new paradigm. Journal of Theoretical and Applied Electronic Commerce Research, 4(3), 17-29. doi:10.4067/S0718-18762009000300003

Wixom, B. H., \& Todd, P. A. (2005). A theoretical integration of user satisfaction and technology acceptance. Information Systems Research, 16(1), 85-102. doi:10.1287/isre.1050.0042

Wixom, B. H., \& Watson, H. J. (2001). An empirical investigation of the factors affecting data warehousing success. Management Information Systems Quarterly, 25(1), 17-41. doi:10.2307/3250957

Xu, D., Benbasat, I., \& Cenfetelli, R. T. (2013). Integrating service quality with system and information quality: An empirical test in the e-service context. Management Information Systems Quarterly, 37(3), 777-794. doi:10.25300/MISQ/2013/37.3.05

Yamaguchi, J. (1997). Positive vs. negative wording. Rasch Measurement Transactions, 11(2), 567.

Yoo, B., \& Donthu, N. (2001). Developing a scale to measure the perceived quality of an Internet shopping site (SITEQUAL). Quarterly Journal of Electronic Commerce, 2, 31-46.

\section{ENDNOTES}

For example, past research has identified lists of desirable functions for online commerce sites (Cenfetelli, Benbasat \& Al-Natour, 2008) and e-government sites (Tan, Benbasat \& Cenfetelli, 2013). 


\section{APPENDIX A}

Table 6. Survey instrument

\begin{tabular}{|c|c|c|}
\hline Construct & Loading & $\begin{array}{c}\text { Items } \\
\text { (Note: ___ was replaced with the relevant website's name in the survey) }\end{array}$ \\
\hline \multirow[t]{2}{*}{ Attitude } & .88 & ATT1: Using __ constitutes a pleasant experience. \\
\hline & .90 & ATT2: Using __is a bad experience. \\
\hline \multirow{2}{*}{$\begin{array}{l}\text { Perceived } \\
\text { Ease of Use }\end{array}$} & .91 & \multirow{2}{*}{$\begin{array}{l}\text { PEOU1: } \_ \text {is easy to use. } \\
\text { PEOU2: Using __ requires a lot of effort. }\end{array}$} \\
\hline & .73 & \\
\hline \multirow{2}{*}{$\begin{array}{l}\text { Perceived } \\
\text { Usefulness }\end{array}$} & .85 & PU1: ___ enables me to accomplish my work more rapidly. \\
\hline & .86 & PU2: Using ___enhances my capacity to make good decisions in my work. \\
\hline \multirow{2}{*}{$\begin{array}{l}\text { Information } \\
\text { Quality }\end{array}$} & .89 & IQ1: I would give a high mark to the information provided on \\
\hline & .88 & IQ2: __ provides me with low-quality information. \\
\hline \multirow{2}{*}{$\begin{array}{l}\text { System } \\
\text { Quality }\end{array}$} & .74 & SQ1: I would give a high mark to ___s functioning. \\
\hline & .86 & SQ2: ___ does not function well. \\
\hline \multirow{2}{*}{$\begin{array}{l}\text { Navigation } \\
\text { Quality }\end{array}$} & .85 & ND1: I would give a high mark to ___s navigation tools (menus and links). \\
\hline & .85 & ND2: Navigation tools (menus and links) are ineffective in helping me navigate _.. \\
\hline \multirow{2}{*}{$\begin{array}{l}\text { Page Layout } \\
\text { Quality }\end{array}$} & .91 & PLQ1: Finding information inside ___'s pages is easy. \\
\hline & .85 & PLQ2: It is difficult to clearly identify the relevant information inside ___'s pages. \\
\hline \multirow{2}{*}{$\begin{array}{l}\text { Visual } \\
\text { Quality }\end{array}$} & .91 & VD1: The visual appearance of ___ is of high quality. \\
\hline & .90 & VD2: The visual appearance of __ is unpleasant. \\
\hline
\end{tabular}

Note: All study items were measured using 5-point Likert scales. Italics indicate negatively worded items 


\section{APPENDIX B}

Table 7. Measurement variance between groups

\begin{tabular}{|c|c|c|c|c|c|c|c|}
\hline \multirow[b]{2}{*}{ Construct } & \multirow[b]{2}{*}{ Indicator } & \multicolumn{2}{|c|}{ FEDE vs. MINIS } & \multicolumn{2}{|c|}{ FEDE vs. PRIV } & \multicolumn{2}{|c|}{ PRIV vs. MINIS } \\
\hline & & $\begin{array}{c}\text { Outer } \\
\text { Loading } \\
\text { Difference }\end{array}$ & p-Value & $\begin{array}{c}\text { Outer } \\
\text { Loading } \\
\text { Difference }\end{array}$ & p-Value & $\begin{array}{c}\text { Outer } \\
\text { Loading } \\
\text { Difference }\end{array}$ & p-Value \\
\hline \multirow{2}{*}{$\begin{array}{l}\text { Information } \\
\text { Quality }\end{array}$} & IQ1 & .071 & 699 & .034 & .192 & 0.038 & .512 \\
\hline & IQ2 & .054 & .726 & .003 & .441 & 0.051 & .697 \\
\hline \multirow{2}{*}{$\begin{array}{l}\text { Page Layout } \\
\text { Quality }\end{array}$} & PLQ1 & .054 & .227 & .078 & .906 & 0.024 & .581 \\
\hline & PLQ2 & .061 & .059 & .097 & .138 & 0.158 & .006 \\
\hline \multirow{2}{*}{$\begin{array}{l}\text { Navigation } \\
\text { Quality }\end{array}$} & NAV1 & .007 & .56 & .114 & .03 & 0.108 & .032 \\
\hline & NAV2 & .081 & .244 & .1 & .841 & 0.019 & .509 \\
\hline \multirow{2}{*}{$\begin{array}{l}\text { Perceived Ease } \\
\text { of Use }\end{array}$} & PEOU1 & .048 & .232 & .083 & .134 & 0.131 & .002 \\
\hline & PEOU2 & .02 & .348 & .032 & .73 & 0.013 & .475 \\
\hline \multirow{2}{*}{$\begin{array}{l}\text { Perceived } \\
\text { Usefulness }\end{array}$} & PU1 & .148 & .904 & .007 & .416 & 0.142 & .855 \\
\hline & PU2 & .063 & .266 & .129 & .147 & 0.192 & .037 \\
\hline \multirow{2}{*}{ System Quality } & SQ1 & .007 & .58 & .218 & .006 & 0.211 & .006 \\
\hline & SQ2 & .034 & .661 & .061 & .18 & 0.027 & .361 \\
\hline \multirow{2}{*}{ Attitude } & ATT1 & .028 & .279 & 0 & .462 & 0.028 & .247 \\
\hline & ATT2 & .025 & .193 & .005 & .39 & 0.03 & .112 \\
\hline \multirow{2}{*}{ Visual Quality } & VQ1 & .027 & .183 & .049 & .063 & 0.076 & .022 \\
\hline & VQ2 & .02 & .264 & .058 & .135 & 0.078 & .064 \\
\hline \multicolumn{2}{|l|}{ Average } & .047 & .402 & .067 & .326 & .083 & .282 \\
\hline
\end{tabular}

\section{APPENDIX C}

\section{Common Method Bias}

Two approaches were used to examine common method variance (Podsakoff et al. 2003) and to assess the risk that common method variance might bias the study results.

First, an approach suggested by Liang et al. (2007) was used, as it helps to avoid LISREL's identification problem and helps to deal with PLS' inability to specify a variable as a measurement indicator of more than one construct. As can be seen in the results reported in Table 8, after converting each indicator to a single-indicator construct, and adding paths from the common method factor to all indicators, the second-order reflective model was estimated. Comparison of each item's path coefficient from its latent to its path coefficient from the common method factor indicated significantly higher path coefficients for the substantive model. In addition, the variance explained by the substantive factors was much larger than the variance explained by the common method factor ( $80 \%$ vs. 1.3\%), indicating that common method bias was unlikely to have influenced the study results.

Second, another analysis was done by using the PLS marker variable approach (Rönkkö and Ylitalo, 2011). Their suggested 5-step approach relies on the use of marker variables to specify a method factor that is included in the research model as a predictor of all its endogenous constructs, and was applied as follows: 
Table 8. Common method bias analysis using Liang et al.'s (2007) approach

\begin{tabular}{|c|c|c|c|c|c|}
\hline Construct & Indicator & $\begin{array}{c}\text { Substantive } \\
\text { Factor Loading } \\
\left(\mathbf{r}_{1}\right)\end{array}$ & $\mathbf{R}_{1}{ }^{2}$ & $\begin{array}{l}\text { Method Factor } \\
\text { Loading }\left(\mathbf{r}_{2}\right)\end{array}$ & $\mathbf{R}_{2}{ }^{2}$ \\
\hline \multirow{2}{*}{$\begin{array}{l}\text { Information } \\
\text { Quality }\end{array}$} & IQ1 & .971 & .9428 & -.087 & .008 \\
\hline & IQ2 & .832 & .692 & .086 & .007 \\
\hline \multirow{2}{*}{ System Quality } & SQ1 & .996 & .992 & -.116 & .013 \\
\hline & SQ2 & .797 & .635 & .114 & .013 \\
\hline \multirow{2}{*}{$\begin{array}{l}\text { Navigation } \\
\text { Quality }\end{array}$} & NAV1 & .672 & .451 & .226 & .051 \\
\hline & NAV2 & 1.025 & 1.050 & .243 & .059 \\
\hline \multirow{2}{*}{$\begin{array}{l}\text { Page Layout } \\
\text { Quality }\end{array}$} & PLQ1 & .94 & .883 & -.07 & .005 \\
\hline & PLQ2 & .83 & .688 & .074 & .005 \\
\hline \multirow{2}{*}{ Visual Quality } & VIS1 & 1.00 & 1 & -.11 & .012 \\
\hline & VIS2 & .847 & .717 & .107 & .012 \\
\hline \multirow{2}{*}{ Attitude } & USAB1 & .90 & .81 & .013 & .0002 \\
\hline & USAB2 & .927 & .859 & -.013 & .0002 \\
\hline \multirow{2}{*}{$\begin{array}{l}\text { Perceived Ease } \\
\text { of Use }\end{array}$} & PEOU1 & .871 & .758 & .038 & .002 \\
\hline & PEOU2 & .914 & .835 & -.040 & .002 \\
\hline \multirow{2}{*}{$\begin{array}{l}\text { Perceived } \\
\text { Usefulness }\end{array}$} & PU1 & .759 & .576 & .182 & .033 \\
\hline & PU2 & .963 & .927 & -.204 & .042 \\
\hline Average & - & .89 & .80 & .02 & .013 \\
\hline
\end{tabular}

Step 1: The marker variables were selected by choosing two indicators that measured respondents' familiarity with (i) the web and (ii) with computers in general. These two indicators were chosen because (i) they had been measured in the survey, and (ii) they were considered as being the least likely to correlate with the variables of the research model. As noted by Rönkkö and Ylitalo (2011): "An ideal candidate for a marker variable should be minimally correlated with the indicators of the study variables" (Lindell \& Whitney, 2001).

Step 2: A primary test of method variance was conducted. To do so, the mean correlations between the two marker items identified in the previous step and the research model's items were calculated (Table 9). Because (i) an average correlation of .08 was observed, and (ii) the rule of thumb for suspecting common method variance is a mean correlation that is superior to .05 , the analysis continued.

Step 3: The baseline model was estimated without any marker variable.

Step 4: Another model which included a new construct, measured reflectively with the two marker variables, was estimated. This construct was modeled as an influence on all other endogenous constructs of the research model (i.e., all model constructs, except Visual Quality).

Step 5: The models of Steps 3 and 4 were compared and all the paths that were significant in the baseline model were found to remain significant in the marker variable model. Hence, the final results that are reported in the present paper are those that were obtained when assessing the baseline model. 
Table 9. Primary test of common method variance in Rönkkö and Ylitalo's (2011) approach

\begin{tabular}{|c|c|c|c|}
\hline Construct & Indicator & $\begin{array}{l}\text { Absolute Correlations Between } \\
\text { the Research Model Items and } \\
\text { Familiarity With the Web Item }\end{array}$ & $\begin{array}{l}\text { Absolute Correlations Between } \\
\text { the Research Model Items and } \\
\text { Familiarity With Computers } \\
\text { Item }\end{array}$ \\
\hline \multirow[t]{2}{*}{ Information Quality } & IQ1 & .019 & .008 \\
\hline & IQ2 & .044 & .019 \\
\hline \multirow[t]{2}{*}{ Page Layout Quality } & PLQ1 & .054 & .093 \\
\hline & PLQ2 & .008 & .045 \\
\hline \multirow[t]{2}{*}{ Navigation Quality } & NAV1 & .210 & .016 \\
\hline & NAV2 & .024 & .096 \\
\hline \multirow{2}{*}{ Perceived Ease of Use } & PEOU1 & .125 & .276 \\
\hline & PEOU2 & .008 & .023 \\
\hline \multirow[t]{2}{*}{ Perceived Usefulness } & PU1 & .087 & .056 \\
\hline & PU2 & .061 & .053 \\
\hline \multirow[t]{2}{*}{ System Quality } & SQ1 & .164 & .142 \\
\hline & SQ2 & .020 & .059 \\
\hline \multirow[t]{2}{*}{ Attitude } & ATT1 & .089 & .165 \\
\hline & ATT2 & .147 & .050 \\
\hline \multirow[t]{2}{*}{ Visual Quality } & VQ1 & .113 & .095 \\
\hline & VQ2 & .121 & .092 \\
\hline \multicolumn{2}{|l|}{ Average } & .080 & .081 \\
\hline
\end{tabular}

Henri Barki is an Emeritus Professor of Information Technologies from HEC Montréal. A member of the Royal Society of Canada since 2003, he has served on the editorial boards of MIS Quarterly, Data Base for Advances in Information Systems, Canadian Journal of Administrative Sciences, Gestion, and Management International. His main research interests have focused on the development, introduction and use of information technologies in organizations. Journals where his research has been published include Canadian Journal of Administrative Sciences, Data Base for Advances in Information Systems, Foundations and Trends in Information Systems, IEEE Transactions on Professional Communication, Information Systems Journal, Information Systems Research, Information \& Management, INFOR, International Journal of Conflict Management, International Journal of e-Collaboration, International Journal of e-Government Research, Journal of the AIS, Journal of Information Technology, Journal of MIS, Management Science, MIS Quarterly, Organization Science, and Small Group Research.

Camille Grange is an Associate Professor of Information Technology at HEC Montréal. She holds a Ph.D. from the Sauder School of Business, University of British Columbia. Her main research interests focus on how individuals interpret, use, and leverage information technologies for desired outcomes. Journals where her research has been published include the European Journal of Information Systems, Information \& Management, and Information Systems Research. 